\title{
Hegemony in International Society. Conceptual and Methodological Proposal towards a New Analytical Framework
}

\author{
Montserrat PINTADO*
}

\begin{abstract}
Hegemony has been a widely debated concept in the discipline of International Relations. However, analyses tend to confuse notions of primacy and hegemony and, therefore, foster the gap between material and social structures. The present article aims to propose an eclectic methodology that examines both material and social structures towards a comprehensive analysis of hegemony. This way, it is possible to understand the bases of hegemony both materially and socially, examining the material power of the hegemon as well as the social structure created by the system's leader. Along all these variables, legitimacy is considered a transversal variable to analyse hegemony, as changing legitimacy principles constitute cornerstone events on the continuity and change of the international society.
\end{abstract}

Keywords: Hegemony - International - Society - Legitimacy

\section{(A) INTRODUCTION}

In the discipline of International Relations, there coexist a wide range of lenses to conceptualize and analyse hegemony. Needless to say, some of these visions are considered rivals or even antagonistic. However, the aim of this research is to converge different paths towards a more comprehensive and complete approach to hegemony that diminishes the barriers between paradigms. In doing so, it is particularly useful to think about research not as dividing, but as a bridge building practice, tackling such important topics through an analytical eclecticism. As Sil and Katzenstein suggest, these eclectic approaches stimulate the transgression of theoretical boundaries both in the research questions and in the perspectives of the discipline ${ }^{\mathrm{I}}$. This way, it will be possible to identify logics that rely on different paradigms and bear with the complexity of some phenomena as the present one $e^{2}$

Often build on opposition to other theories, paradigms usually highlight several faces of the phenomenon while obscuring others. Moreover, IR as a discipline often bears with several events that do not necessarily fit into the expectations of theories ${ }^{3}$. Taking that into account, it is possible to argue that an eclectic framework has more chances to minimize these anomalies by opening the analytical scope.

In the case of hegemony, different approaches stand into divergent definitions of the term that, hence, provide alternative answers. Therefore, it should be clearly stated which question will be addressed and

\footnotetext{
PhD on International Studies and Assistant Professor, University of the Basque Country (UPV/EHU).

${ }^{I}$ R. Sil and P. J. Katzenstein, Beyond Paradigms. Analytic Eclecticism in the Study of World Politics, (Palgrave Macmillan, Basingstoke, 20I0) at 2I.

Ibid, at 19 .

3 The end of the Cold War and the advent of unipolarity caught several scholars by surprise. As a result, some delayed for years the proclamation of unipolarity. Examples include prominent scholars such as Waltz, Kaplan or, to some point, Krauthammer. See K. N. Waltz., "The Emerging Structure of International Politics", I8(2) International Security, (1993) 44-79 [doi: 10.2307/2539097]; R. D. Kaplan, The Coming Anarchy. Shattering the Dreams of the Post Cold War, (Random House, New York, 2000); C. Krauthammer, "The Unipolar Moment", 70(I) Foreign Affairs, (1990/199I) 23-33 [doi: 10.2307/20044692].
} 
what each term means. As a starting point, hegemony will be understood as an eclectic concept bringing together features highlighted by different theoretical traditions. Concretely, for the purpose of this research, hegemony will be understood as an institution of the international society. Hence, an English School framework will be applied, even though contributions of other schools of thought will be applied to enrich and criticize this view. Under this approach, hegemony is defined as a relation of social and informal hierarchy build on a legitimized and socialized international order. This order is mainly composed of a strong institutional network and a dominant set of identities, interests, and practices underpinned by an extraordinary portfolio of material capabilities and resources ${ }^{4}$. In other words, hegemony is embedded on a hierarchical network model, in the words of Oatlet, Winecoff, Pennock and Danzman. However, the hierarchical network model proposed by these authors differs from the traditional hegemonic structure. In the former state capabilities and influence are derivative from the network, whereas in the later the structure is derivative from the capabilities of the units.

However, as the definition of hegemony exemplifies, the conceptualization of the concept of international order is complex. Even though some have defined it solely as a reflection of the material distribution of power, as Gilpin did, the international order has also a societal nature as a pattern of the international behavior that advances towards the primary goals of the society such as preserving peace and state sovereignty or the endurance of the system and the international society'.

International order, nowadays, is hybrid not only by its composition, but also in the coexistence of anarchical and hierarchical structures within it. While anarchy refers to the absence of governments and/or rule, hierarchy is related to specific relations of subordination or domination. This hybridity is essential to understand the contemporary international order and, moreover, to better conceptualize its shape and future development. In this equation, hegemony is the result of a unipolar polarity and superordinate authority that creates a certain form of hierarchy that takes place in an anarchical

4 For the composition of this definition, I have relied mainly on several conceptualizations of the concept considered as constructivist or English School's. See I. Clark, Hegemony in International Society, (Oxford University Press, Oxford, 20II); C. Beyer, "Hegemony, Equilibrium and Counterpower: A Synthetic Approach", 23(3) International Relations, (2009) 4II-427, [doi: I0.II77/0047II7809340499]; M. Bukovansky, Legitimacy and Power Politics: The American and French Revolutions in International Political Culture, (Princeton University Press, Princeton, 2010). However, it should be noted that the exploration of a common ground that the English School and constructivism share regarding hegemony does not necessarily omit the differences between these two theoretical traditions. In fact, theorists from both perspectives have explored the common grounds (mainly, their concern for the social dimensions in the analysis of the international realm) as well as their differences. Several authors get more in deep on the common grounds and differences of both theories. See, for example, T. Dunne, "The Social Construction of International Society", I(3) European Journal of International Relations, (1995) 367-389 [doi: I0.II77/1354066rg5001003003]; T. Dunne, Inventing International Society: A History of the English School (Macmillan, London, 1998); C. Reus-Smit, "Imagining Society: Constructivism and the English School", 4(3) British Journal of Politics and International Relations, (2002) 487-509 [doi: 10.mi/1467-856X.00091]; C. Navari and D. M. Green (ed.), Guide to the English School on International Studies (Wiley Blackwell, Chichester, 20I4); C. Navari (ed.), Theorising International Society: English School Methods (Palgrave Macmillan, Basingstoke, 2009).

5 T. Oatley et al., "The Political Economy of Global Finance: A Network Model", II I I) Perspectives on Politics, (20I3) I33-153, at I36 [doi: 10.1017/SI537592712003593].

6 R. Gilpin, War and Change in World Politics, (Cambridge University Press, Cambridge, 198I); H. Bull, The anarchical Society. A Study of Order in World Politics, (Palgrave, London, 2002) at 8. For a further exploration of different conceptualizations of the notion of international order, see J. A. Hall, International Order (Polity Press, Cambridge, 1996); J. M. Parent and E. Erikson, "Anarchy, hierarchy and order", 22(I) Cambridge Review of International Affairs, (2009) I29-145 [doi: 10.1080/09557570802683912]. 
environment? .

Even if this definition mentions material resources as a source of hegemonic power like realists do, the present article does not understand them as the main components of hegemony. Material capabilities constitute the cornerstone of primacy or unipolar structures ${ }^{8}$. As Ikenberry argues in the case of the United States after WWII, the new redistribution of power offers to the unipole a broad bunch of choices including domination, transformation or abandonment?. Whatever the unipole decides, the outcomes are not automatic, agency is involved. In this case, the transformation of these power disparities into hegemony constitutes a conscious strategy of order creation and institutional restraint.

In this process, the unipole's identity, interests, and recurrent practices are translated into the progressive institutional web. Although it was constructed with a global ambition, the postwar order was liberal and Western in its identity and practices. It can be argued that the creation of a normative and institutional order is a probe of the impossibility of maintaining the stability of the system only through material power and public goods' provision. Institutional binding offers stability and reduces leadership costs, but at the same time restraints the exercise of the hegemon's power. To achieve these gains, the unipole needs to socialize and legitimize this order. As Clark remarks, the legitimating practices under hegemony do not legitimate a particular state's exercise of power, but the order it has built ${ }^{\mathrm{T}}$.

Even if this definition brings together several aspects highlighted by the main theories of the discipline, there can be identified several points of disagreement between them that may contribute to the enrichment of the concept.

\section{(B) MATERIAL AND SOCIAL VARIABLES IN THE ANALYSIS OF INTERNATIONAL SOCIETY.}

\section{CONVERGING PERSPECTIVES}

The main approaches of the discipline are usually divided by its emphasis on material or social factors. Even if the materialist perspective led by realism constitutes the main lens to analyse the international, the end of the Cold War has boosted many social analyses to the main debates. The materialist approach's principal works portray hegemony as a result of the accumulations of high amounts of material power. Even if this approach has been usually attached to the realist tradition in its broader sense, it is undeniable that the material analysis has commonly been used as a ground to develop other theories, such as neoliberalism. As Ikenberry put it, polarity and power distributions only offer a

7 J. Donnelly, "Sovereign Inequalities and Hierarchy in Anarchy: American Power and International Society", I2(2) European Journal of International Relations, (2006) I39-I70, at I39 and I4I-I42. [doi: 10.II77/I354066106064505].

8 Hegemony and unipolarity/primacy are terms commonly seen as synonyms. However, unipolarity and primacy describe a situation of preponderance of capabilities. Hegemony, in contrasts, defines a unipolar configuration in political and economic terms that results in a structure of influence. D. Wilkinson, "Unipolarity Without Hegemony", I(2) International Studies Review, (1999) I4I-I72, at I43, [doi: I0.III/I52I-9488.00I58]; Clark, supra n. 4, at 34.

9 G. J. Ikenberry, After Victory. Institutions, Strategic Restraint and the Rebuilding of Order after Major Wars, (Princeton University Press, Princeton, 200I) at 3-4.

Io I. Clark, "China and the United States: A Succession of Hegemonies?", 87(I) International Affairs, (20II) I3-28, at 24, [doi: Io.IIII/j.I468-2346.20II.00957.x]. 
description of national capabilities but cannot explain the political formation that the hegemon builds around these material assets ${ }^{\text {II }}$. In other words, if the possession of several material capabilities was the sole indicator, the results will only determine the polarity of the system or, more precisely, to what extent it remains the United States' primacy over the system.

The second perspective, focused on social variables, has been explored from a great range of theories that have added different social variables to their analysis. At this point, it is important to remember that different kinds of social variables coexist within the liberal, constructivist, English School and Chinese Approaches (mainly in the theory of relationality by Qin Yaqing but also in Yan Xuetong's Moral Realism). It is widely known that an analysis of systemic transformations and, more precisely, of hegemony and rising states, must tackle the question of how the order has been constructed by the dominant state. Material capabilities cannot determine nor the exercise of power, neither the building of the hegemonic order ${ }^{12}$. In the task of disentangling the superstructure of the United States hegemonic institution, several variables must be addressed through a qualitative methodology. Following Clark's works on hegemonic institutions, it is possible to point that legitimacy will play a crucial role ${ }^{\text {r3 }}$, not forgetting the importance of socialization or identity.

Undoubtedly, an analysis of material distributions of power provides interesting information about the structure of the system and the constrains faced by great powers. Even constructivism admits that changes in the distribution of power matter, because they produce changes in great powers' attitudes towards the normative structure, pushing them to defend, oppose or even boost new norms ${ }^{14}$. However, in cases of high imbalances of power as the present one, materialist analyses say little about the international order built by the powerful state. It is true that material preponderance or primacy offer multiple opportunities to the dominant state to spread its influence and strength, but there is a need to legitimate it and construct a hegemonic status ${ }^{15}$. Therefore, primacy constitutes the first and compulsory step towards hegemony, but a materially dominant state does not always become a hegemon. In other words, hegemony is a socially achieved status, built on rights, consent, and legitimacy. Moreover, this distinction unfolds what it is usually called as hegemonic decline in two (intertwined) phenomena. The first, related to primacy and the inability of the dominant state to maintain itself as a world leader in terms of resources and capabilities. The second one is the crisis of the social order built by the hegemon to sustain its position. Both faces of the same coin, hegemony needs primacy, but primacy does not

II G. J. Ikenberry, Liberal Leviatban. The Origins, Crisis, and Transformation of the American World Order, (Princeton University Press, Princeton, 2012) at. 46-47.

I2 Ibid. at 39 .

I3 See Bukovansky, supra n. 4; I. Clark, Legitimacy in the International Society, (Oxford University Press, Oxford, 2005): M. Finnemore, "Legitimacy, Hypocrisy, and the Social Structure of Unipolarity. Why Being a Unipole Isn't All it's Cracked Up to Be", 6I(I) World Politics, (2009) 58-85, [doi: I0.I0I7/S0043887109000082]; D. P. Rapkin and D. Braaten, "Conceptualising Hegemonic Legitimacy", 35(I) Review of International Studies, (2009) II3-I49, [doi: I0.1017/S0260210509008353].

${ }^{14}$ A. R. Young, "Perspectives on the Changing Global Distribution of Power: Concepts and Context", 30(I) Politics, (2010) 2-I4, at 4, [doi: I0.III/j.I467-9256.2010.01390.x]; R. Price, "Reversing the Gun Sights: Transnational Civil Society Targets Land Mines", 52(3) International Organization, (1998) 613-644, at 635, [doi: 10.1162/002081898550671].

is I. Hurd, "Breaking and Making Norms: American Revisionism and Crisis of Legitimacy", 44(2/3) International Politics, (2007) 194-213, at 204, [doi: 10.1057/palgrave.ip.8800I84]. 
necessarily imply hegemony. Thus, any analysis of hegemony must address both realities: the power structure and the social order ${ }^{16}$.

In this vein, it is necessary to advance towards a reconciliation of material and social approaches to understand, as Beyer notes, US predominance in a multidimensional way ${ }^{17}$. Material power should be understood as the way to achieve the monopoly of the production of cultural, social and symbolic capital justified and legitimized through multiple social structures ${ }^{18}$.

As Guzzini rightly noted, the nature of international society does have an impact on the value of abilities, resources and the relevant issue areas ${ }^{19}$. Understanding the contemporary environment in a complex way — not just as a Hobbessian order, but with mixed characteristics of Lockean and Kantian societies - any materialist view should understand power resources as, at the same time, hybrid and in constant evolution.

Moreover, what materialist lenses cannot explain is the character and the relationship between emerging powers and the international order. Materialist scholars tend to portray rising states as potentially dangerous, understanding that rising powers will likely use their material status to overturn the system. However, as others point out, the dissatisfaction of the rising state cannot be taken for granted. At this point, it is possible to agree with Schweller and $\mathrm{Pu}$ when they highlight that the future international order and a hypothetical rise of unipolarity depend directly on the roles played by emerging powers. In this vein, they draw three alternative options, going from support to the order and sharing of responsibilities, spoiling and dismantlement of the existing order and replacement, and finally, a free rider behavior that gets the privileges of this power position without contributing to global governance ${ }^{20}$.

Definitely, states' attitudes towards the international system are not solely materially determined. One can argue, as some realist did, that states with growing capabilities will definitely be revisionist or/and challengers ${ }^{21}$, but as the hegemonic succession between the United Kingdom and the United States exemplifies, some transitions can be progressive and peaceful. Therefore, the rise of the conflict not only depends on how the emergent state behaves, but also how the former hegemon manages its decline.

At this point, the identities that the rising state performs gain special attention. However, it is necessary to have in mind that great powers' rise not only involves the emerging state, but also the relation between this state, on the one hand, and the hegemon and the international order it has built, on the other. Therefore, it constitutes a two-way process that cannot be isolated. As Buzan and Cox

I6 The distinction between power structure and social order as components of hegemony is developed by Barry Buzan.

B. Buzan, The United States and the Great Powers. World politics in the twenty-first century, (Polity, Cambridge, 2004) at 48.

i7 Beyer, supra n. 4.

I8 R. L. Schweller and Pu X., "After Unipolarity. China's Visions of International Order in an Era of U.S. Decline”, 36(I) International Security, (201I) 4I-72, at 49, [doi: I0.II62/ISEC_a_00044].

19 S. Guzzini, "From (alleged) unipolarity to the decline of multilateralism? A power-theoretical critique" in E. Newman, R. Thakur and J. Turman (eds.), Multilateralism under challenge? Power, international order and structural change, (United Nations University Press, New York 2006) I19-I38, at 124.

$20 \quad$ R. L. Schweller and Pu X., supra n. I8.

2I Examples include, among others, J. J. Mearsheimer, The Tragedy of Great Power Politics, (Norton, Nueva York, 200I); R. Gilpin, "The Theory of Hegemonic War", I8(4) The Journal of Interdisciplinary History, (1988) 591-6I3 [이: 10.2307/204816]. 
summarize, rising powers can emerge conflictively or peacefully. The conflictual scenario, as drawn by realism, supposes that emerging powers will try to overturn the system to gain the most. On the contrary, the peaceful model involves a war free scenario, although the negative peaceful rise may involve growing threateningly. This taxonomy suggests that, for peaceful rise to be achieved, the rising power should be able to get both material and social gains in absolute and relative terms without the need to precipitate an open as war ${ }^{22}$. Undoubtedly, the hegemon has in its hands the chance to accommodate the rising power and balance the gain and status inequality to improve rising state's satisfaction with the system, but it will inevitably narrow the gap between both states' relative power distribution and conflict with the hegemon's own interests.

(C) THE ROLE OF INSTITUTIONS IN INTERNATIONAL SOCIETY. CONSTRUCTION, CHANGE, AND ACCOMMODATION IN INSTITUTIONALIZED SOCIAL ORDERS

The international order constructed around the hegemon's dominance is a topic of special concern for various IR scholars. As Clark points out, hegemonic legitimacy is bestowed no to the actor itself, but to the institutional order it has built around its power ${ }^{23}$. However, that order may have different characteristics and suffer transformations in response to the changing systemic dynamics. As a response to the latest changes in the distribution of power, scholars hold the expectation that these changes will challenge the US liberal institutional order ${ }^{24}$. It should be noted that the order build by the hegemon is not only rooted in institutions, but also in informal norms, meanings, and behaviors. Therefore, institutions constructed by the hegemon are not the only important objects of study, but also the underlying doctrines of this institutional net ${ }^{25}$.

The focus on institutions builds a bridge between the social approaches of the English School and constructivism, on the one hand, and the liberal institutionalist approach, especially in the analysis of the contemporary liberal order, on the other. On the contrary, realism does not pay much attention to institutions, understanding them as a result of power distributions and created for selfish purposes ${ }^{26}$. However, it is possible to agree that institutions are, at first, created for achieving these selfish outcomes, mainly for locking the leadership in the system by a wide institutional practice. As even critical theorists

22 B. Buzan and M. Cox, "China and the US: Comparable Cases of 'Peaceful Rise", 6(2) The Chinese Journal of International Politics, (2013) I09-I32, at II2, [https://doi.org/I0.I093/cjip/potoo3].

23 Clark, supra n. IO, at 24.

24 Young, supra n. I4, It 4.

25 For this author, institutions are defined as a corpus of norms, rules, and principles that have the capacity to transform social relations. Institutions and international organizations usually play a key role as legitimizers of the hegemon's exercise of power and, to that extent, they also get weakened by several hypocritical behaviors of the hegemon. In Reus-Smit's words, political power is tightly rooted in the network or social interchange and mutual constitution. Hence, legitimacy and institutions become the bases of stable political power as the institutionalization of the hegemonic power transforms the social structure of the system. C. Reus-Smit, American Power and World Order, (Polity Press, Cambridge, 2004) at 4I. Gradually, these institutions become stronger non-state actors and gain autonomy from the hegemonic power and, at the same time, stabilize and transform the international realm, setting new goals that slowly become socialized both for the hegemon and for the rest of the states on the international society. Finnemore, supra n. I3, at 6r.

26 J. J. Mearsheimer, "The False Promise of International Institutions", 19(3) International Security, (1994-1995) 5-49, at 7 , [doi: $10.2307 / 2539078]$. 
admit, hegemony is extremely linked to the model of international order that the hegemon wants to lead ${ }^{27}$, a project in which institutions are essential tools. Going further, in the international society approach, Clark suggests that hegemony can be defined as a "legitimated social arrangement" in which institutions play a crucial role $e^{28}$. So, rather than as a way to administrate hegemony, institutions must be taken as its cornerstone.

Nevertheless, the institutional practices make these institutions less dependent upon the hegemon, at least apparently. As Keohane concluded, international regimes can survive hegemony ${ }^{29}$. However, that conclusion seems risky, as the survival of regimes is highly linked to the character of the new international order that arises after the decline of the hegemon. In other words, it must be theorized to what extent the new unipole will support the institutions that mirror a share of gains related to the old distribution of power. It may be possible to envisage a gradual irrelevance of the institutions or the rise of new institutional frameworks that serve the same needs but that accommodate better to the new world order.

Moreover, the important question to be addressed is to what extent do international norms and institutions constraint material power ${ }^{30}$. This way, it is possible also to question the impact of changes in the material distribution on the institutional and normative structure of the international society and the accommodation of rising powers to the existing system. Needless to say, institutions are an important point of analysis of a state's compliance with the status quo. A pro status quo power agrees both with the institutions of the international society and also with its status within them. Therefore, as these regimes reflect an unbalanced distribution of power, rising states do not usually agree with its status and try to improve it and push for a new distribution. Hence, they constitute unequal grounds of negotiation and not a multilateral structure as it is sometimes pretended.

The hypothetical process of accommodation of the new poles, especially China, may involve a change in the conception of governance. In the western understanding, governance is focused on institutions, both formal and informal, and processes conceived to guide and restraint states' activities ${ }^{31}$. However, it is not a unique conception of governance. As Qin suggests, relational governance is more rooted in Confucian cultures as a form of governance that does not govern actors but relationships. With its multidimensional character, it is not about control, but about negotiation ${ }^{32}$.

As this comparison shows, the identity of the ruling elites is embedded in the character of the international order. Therefore, different actors have different relationship with the order, as the sharing

27 R. W. Cox, Approaches to World Order, (Cambridge University Press, Cambridge, 1996) at 136.

${ }_{28}$ Clark, supra n. 4, at 4. It should be noted that Clark makes a distinction between primary institutions of the international society (war, international law, balance of power or hegemony, among others) and secondary institutions (or international organizations).

29 R. O. Keohane, After Hegemony. Cooperation and Discard in the World Political Economy, (Princeton University Press, Princeton, 1984).

30 I. Clark, "International Society and China: The Power of Norms and the Norms of Power", 7(3) The Chinese Journal of International Politics, (2014) 315-340, at 317, [doi: I0.I093/cjip/potor4].

${ }_{31}$ R. O. Keohane and J. S. Nye, "Governance in a globalising world" in R. O. Keohane (ed.), Governance in a Partially Globalized World, (Routledge, London, 2002) 193-2I8, at 202.

32 Qin Y., "Rule, Rules, and Relations: Towards a Synthetic Approach to Governance", 4(2) The Chinese Journal of International Politics, (20II) II7-I45, at I33, [doi: I0.IO93/cjip/poroo8]. 
of status and the participation is unequal. Understanding the performative role of institutional networks provides clues on the satisfaction of a state with the status quo. In other words, institutions are of special concern to analyse the accommodation of rising powers to the existing order and their relations with the institution of hegemony.

Any approach to the institutional scenario in situations of hegemony should, firstly, consider institutions as organizations in constant evolution that develop their own logics as they become more stable ${ }^{33}$. For the purpose of analysing hegemonic institutional context, it should also be noted the context in which they are born and how this context is transformed after the creation. It is possible to argue that this pre-institutional context is defined by a situation of material primacy of a state for a period that is usually characterized as post conflictual ${ }^{34}$. In this specific moment, the most powerful power decides to institutionalize its exercise of power through a set of regimes, organizations, and norms which are profoundly influenced by its interests and identities. In the afterward of the WWII, for instance, United States promoted the regulation of the international economic and financial systems through the Bretton Woods institutions. This institutional complex, even if created through agreement with other 43 countries, reflected the capitalist and liberal identities of the United States and served to their interest, especially in commercial, monetary and financial terms.

Accordingly, the leading state will achieve several goals with the construction of these institutional networks. On the one hand, and more evidently, it binds secondary states into a certain post-war order that offers predictable patterns of behavior and reduces uncertainty ${ }^{35}$. On the other hand, and more importantly, it constitutionalizes, socializes, legitimates and decentralizes its exercise of power. At the same time, it establishes a certain hegemonic narrative of the international society that contains concrete meanings and boundaries that marginalize other actors and narratives.

Once institutions became the grounds of negotiation and some regular patterns of contacts are established, they influence, in different ways, both actors and the international context. The development of a constitutional international order transforms primacy into hegemony ${ }^{36}$. The outcomes on the international arena can be summarized in the following five. Firstly, as liberals advanced,

33 Ikenberry, supra n. 9, at 42; Finnemore, supra n. 13, at 68-69.

34 Clark, supra n. 4; Ikenberry, supra n. 9.

35 Ikenberry, supra n. 9, at 5I.

36 Even though both Clark and Ikenberry highlight the constitutional nature of certain international orders, their visions differ. Ikenberry describes the chances of the leading state after a war, domination, abandonment or hegemony. The leading state has incentives to construct "a mutually acceptable order" and, towards this goal, the institutionalization of cooperation is the tool to overcome secondary states' fears of domination and abandonment. This way, the leading state's decision to create an institutionalized order in the form of cooperation through international organizations is what legitimizes the hegemon. Clark's view differs in several points. For this author, the international organizations that have been created under US hegemony are secondary institutions derivative from the primary institution of hegemony, adopting English School's terminology. This way, Clark questions the notion that "the principal strategy of hegemony adopted by the United States after the war was itself institutional", which is the basic argument to defend that these institutions are what bestowed the US with legitimacy. In his opinion, the hegemon does not directly create institutions, but an institution of hegemony that contains a certain order and concrete narratives of what is considered as rightful state conduct. Secondary states, at this phase, are the ones who judge the legitimate character of this institution and, eventually, bestow the order that the hegemon has built (or the institution of hegemony) with legitimacy, but not the actor itself. In other words, it is the hegemonic superstructure what is legitimated, not the United States as the hierarchical leader at its top. Ikenberry, supra n. 9, at 5I-53; I. Clark, Hegemony in International Society (Oxford University Press, Oxford, 20II) at54 and I24. 
institutions transform the contexts of cooperation. The availability of more and better information increases trust and multilateral cooperation, as the multiplication of actors does not necessarily imply an increase of cheating options. Secondly, institutions also provide instrumental legitimation to certain hegemonic decisions, as the United States has done, for example, through the establishment of multilateral forces with NATO members for several military conflicts. Thirdly, institutions also become sources of contestation to the hegemon, for example, through veto in the United Nations Security Council. Fourthly, they also constrain the exercise of hegemonic power. They set the boundaries on the exercise of material power, but they also offer different alternatives to the hegemonic state. In the view of Brooks and Wohlforth, constrains emerged from institutions, especially reputation, are minimal ${ }^{37}$. However, their analysis focuses more in the direct constraint, obviating the long term erosion of the hegemon's legitimacy. As Finnemore affirms, the hegemon feels the constraints of institutions through punishment and trap and, as a response to it, develops hypocritical behaviors, eroding its legitimacy ${ }^{3}$. Finally, institutions shape the actors' identity, values, and interest ${ }^{39}$ by promoting, for example, a more important status inside the organization. This accommodation strategy is usually mentioned as a way to promote China's turn into a status quo power. However, the case study should address to what extent contemporary institutions perpetuate the Cold War power distribution and whether they are still reluctant to adjust their power-sharing.

\section{(D) STABILITY IN INTERNATIONAL SOCIETY. THE ROLE OF HEGEMONY AND THE PROSPECTS OF CONTINUITY AND CHANGE}

The stability of the international system is an issue of special concern, considering the anarchical character of the system. In a general sense, stability is linked to the structure of the system, considering some distributions as more stable. Proponents of the Hegemonic Stability Theory pointed to the power inequality as a source of stability, defending that the hegemon plays an important role maintaining the system and providing global public goods such as security or economic order ${ }^{40}$. Moreover, Gilpin stated that hegemony, not anarchy, constituted the organizing principle of the system at least for two decades ${ }^{4}$.

However, in the realist tradition, the balance of power theories continued to link bipolarity with stability, as a source of restriction on the great powers. Hegemonic and balance of power approaches,

37 S. G. Brooks and W. C. Wohlforth, World out of Balance. International Relations and the Challenge of American Primacy, (Princeton University, Princeton, 2008).

${ }_{38}$ Finnemore, supra n. $\mathrm{I} 3$, at $6 \mathrm{I}$.

39 P. J. Katzenstein, The culture of national security: norms and identity in world politics, (Columbia University Press, New York, 1996) at 22; R. D. Duvall and A. Wendt, "Institutions and International Order: Approaches to World Politics for the 1990s" in E.-O. Czempiel and J. N. Rosenau (eds.), Global Changes and Theoretical Challenges: Approaches to World Politics for the 1990s, (Lexington Books, Lexington, 1989) 5I-73, at 60.

40 Even Carr was convinced that the "working hypothesis of an international order was created by a superior power". E. H. Carr, The Twenty Years' Crisis 1919-1939. An Introduction to the Study of International Relations, (Macmillan, London, [1939], 1946) at 232. In the same vein, realists as Wohlforth affirm that the broader is the concentration of power in the hands of the hegemonic state, the more stability and order in the international system. W. C. Wohlforth, "The Stability of a Unipolar World", 24(I) International Security, (1999) 5-41, at 23.

${ }^{4}$ Gilpin refers to the two decades before the publication of his book, War and Change in 198I. Gilpin, supra n. 6, at 7 and 144 . 
despite these confronting arguments, converge on pointing to a particular structure of the system as the source of stability. However, for Gilpin, hegemony needs prestige to overcome the logic of the balance of power. This way, other powers will understand that the hegemon will restrain its power and provide public goods. In other words, the less powerful states decide that they gain more with the rule of the hegemon that with confrontation and balancing. As Power Transition Theory proposes, satisfaction constitutes a key variable in continuity and change, but at the same time is a slippery unit of analysis ${ }^{42}$.

In the same vein, in the realist school, some refuted balance of power theories and declared that it was not polarity, but the balance between status quo and revisionist forces in the system what makes a system stablet3. Again, this statement goes back to the consideration of rising power as a risk to the system. That constitutes a point of convergence in most hegemonic theories and also for some of the pro-balancing scholars. However, the rise of a new power and the distribution of power are not the only variables to consider. As Schweller points out, when explaining the practices of bandwagoning, even if these dynamics push the system in the direction of change, this change may not always mean a more unstable system ${ }^{4}$. Moreover, he also contends that modern realists tend to assume that states would pay higher costs to protect the values they already possess (a status quo position) but would take lower risks to improve their position in the system (revisionist) ${ }^{45}$. Undoubtedly, this dichotomy goes back to the realist debate over which one is states' primary goal, security or power. Yet, this distinction is false to the extent that ignores the changing goals of emerging states, the evolution of their interests and its possible accommodation in the system and future satisfaction.

Therefore, the source of stability is not the pattern of power, but the relationship between the power distribution and the international order. Even if the previous approaches may seem as contradictory, they refer to different orders. In this vein, Ikenberry distinguishes between three orders that vary in their sources of stability. In the case of balance of power, there are the balancing practices; in hegemonic orders, the unipole and in constitutional orders is the normative corpus in which the power limiting institutions are based ${ }^{46}$. However, in constitutional orders, it may be argued that institutions per se are not a source of stability, it is the legitimacy bestowed to the order of which these institutions take part that assures the stability of the system. Therefore, legitimacy, and not institutions, is the source of

42 A. F. K. Organski, World Politics, (Alfred A. Knopf, New York, 1965); A. F. K. Organski and J. Kugler, The War Ledger, (University of Chicago Press, Chicago, 1980); J. Kugler and D. Lemke (eds.), Parity and War. Evaluations and Extensions of The War Ledger, (University of Michigan Press, Ann Arbor,1996); D. Lemke, "Great Powers in the Post-Cold War World: A Power Transition Perspective" in T.V. Paul, J. J. Wirtz and M. Fortmann, Balance of Power. Theory and Practice in the 2Ist Century, (Stanford University Press, Stanford, 2004) pp. 52-75; J. Kugler and D. Lemke, "The Power Transition Research Program" in M. I. Midlarsky (ed.), Handbook of War Studies, (University of Michigan Press, Ann Arbor, 2000) pp. 129-163.

43 J. Kirshner, "The Tragedy of Offensive Realism: Classical Realism and the Rise of China", I8(I) European Journal of International Relations, (2012) 53-75, at 58, [doi: 10.II77/I354066110373949]; R. L. Schweller, "Bandwagoning for Profit. Bringing the Revisionist State Back In", I9 (I) International Security, (1994) 72-I07, at 93, [doi: 10.2307/2539149].

44 Schweller, supra n. 43 , at 93.

45 Ibid at 85 .

46 Ikenberry, supra n. 9, at 23-24. 
stability of the system ${ }^{47}$.

Even if we admit that a concrete power pattern generates stability, it does not automatically generate a society ${ }^{48}$. With the absence of a society, conflict would be permanent, because even if the system is stable and has a regular pattern of behavior, different conceptions of how the society should be are in conflict. That is to say, if we analyse the post-war periods with an English School lens, we will not totally agree with Ikenberry's description of these periods as terms used by the victorious great power to construct an order and provide stability. These periods can also be seen as struggles to establish which principles of legitimacy will be hegemonic in the system as happened after WWII. Later, these principles will constitute the cornerstone of the newly born international society. Therefore, the order is not the direct aim, but the outcome of the stabilization of these legitimacy principlest9. So, if we consider that both hegemony and legitimacy constitute social phenomena that involve values (considered to a different extent depending on the theory) ${ }^{\text {so }}$, we can conclude that the international society cannot be stable without the shared values that make possible these bunches of legitimate principles and sanction them as hegemonic and, hence, not even international society.

However, this emphasis on shared values must not be misunderstood with the notion of the standard of civilization, prominent among English School scholars in the last century. It is possible to draw a link to the school's prominent work on The Expansion of International Society. In this work, despite the attention given to the case studies, for Bull and Watson, the individual analyses serve to a more important research question: the new international system. Even if they dedicate a chapter to the emergence of the new international society, the work does not properly address the biggest uncertainties about the global international society, not even its existence, formation or consistency ${ }^{51}$. This gap makes it necessary to address these questions in the case of the contemporary international society: to what extent it is universal? Does it have any entry requirements as it had in previous centuries? The character of international society is again linked to stability, as the inclusion and accommodation of new or peripheral powers in this society and the socialization of the society itself are crucial issues to provide continuity and also to assure that change is less dramatic. The very existence of this society implies shared norms and institutions which, in reality, are usually established by a great power to assure its order. Therefore, this conclusion, besides reinforcing Clark's asseveration that the English School and hegemonic analysis are complementary, also strengths the argument that this society in its universal sense would be better achieved under hegemony. In a hypothetical case of a struggle for systemic dominance, different sets of norms, regimes and alternative hegemonic institutions based on

47 C. Reus-Smit, "International Crisis of Legitimacy", 44(2/3) International Politics, (2007) 157-174, at 170, [doi: I0.1057/palgrave.ip.8800182].

48 C. Navari, "What the Classical English School was Trying to Explain, and Why its Members were not Interested in Causal Explanation" in C. Navari (ed.), Theorising International Society: English School Methods, (Palgrave Macmillan, Basingstoke, 2009) 39-51, at 45 .

49 Y. Zhang, "China and the Struggle for Legitimacy of a Rising Power", 8(3) The Chinese Journal of International Politics, (2015) 30I-322, at 305, [doi: I0.I093/cjip/povoo8].

so I. Clark, "How Hierarchical can International Society be?" in K. Booth (ed.), Realism in World Politics, (Routledge, London, 20II) 27I-287, p. 277.

sI B. Vigezzi, The British Committee on the Theory of International Politics (1954-1985): The Rediscovery of History, (Edizioni Unicopli, Milan, 2005) at roo. 
confronting identities anticipate a fragmentation of the global entity of international society. Change, in this case, cannot be explained just as a power transition, but as a hegemonic succession ${ }^{52}$.

As Clark contends the right of the declining hegemon to keep on institutionalizing an order at its own shape expecting that the eventual successor will simply adapt to it is at least questionables'. In this case, the order will not constitute a source of stability, but of conflict, as a struggle between two alternative hegemonic institutions. In the event of a lack of agreement on the definition of the legitimate hegemonic institutions and as a cause of the transition in progress, it may be possible to witness a fragmentation of international society toward different legitimacy principles and confronting considerations of how international order should be.

\section{(E) METHODOLOGICAL PROPOSAL TOWARDS A COMPOSED UNDERSTANDING OF} HEGEMONY. THE ROLE OF MATERIAL AND SOCIAL VARIABLES

The hybrid nature of the actual contemporary international society and its changing nature complicate any analysis of its structure. Concretely, the present society is hybrid both in its origins and in its expansion. As Hurrell notes, this society is defined by a "deformity" resulted from two phenomena. On the one hand, the interests and preferences of the great powers have an important influence in the society and, on the other, there is growing pluralism of ideas, values, and identities that seek recognition within the society $y^{54}$.

As Buzan and Lawson note, in public policy, the term international society has been usually interchanged with "international community". On the long term, this creates a false understanding that raises an idea of an effective and identity-based community, shadowing the reality of an international society that it is constantly negotiated and pluralist in its coress.

Due to these continuous processes of negotiation, dynamics of contestation regarding the unequal distribution of rights and status are common within international society. This contestation constitutes a force of transformation and globalization of the international society, pushing towards a restructuration of the social relations that take place within it $^{56}$.

This constant evolution results on a changing nature of the society, supported by four main reasons. The first one is the multiplication of non-state actors and their growing relevance in the system. Even if the state continues to be the most important actor for the majority of IR scholarship, the geopolitical relevance of these new poles of power grows dramatically, particularly in the case of terrorist groups, transnational corporations, and cities, among others. Secondly, the society of states is evolving towards

52 Clark, supra n. IO, at I3-I4.

53 Clark, supra n. 4, at I9I.

${ }_{54}$ T. Dunne and C. Reus-Smit, The Globalization of International Society, (Oxford University Press, Oxford, 20I7) at 32.

ss B. Buzan and G. Lawson, The Global Transformation. History, Modernity and the Making of International Relations, (Cambridge University Press, Cambridge, 2015) at 302.

56 A. Hurrell, On Global Order: Power, Values and the Constitution of International Society, (Oxford University Press, Oxford, 2007) at 9-IO; Y. Zhang, "China and the Struggle for Legitimacy of a Rising Power", 8(3) The Chinese Journal of International Politics, (2015) 30I-322, at 306, [doi: I0.I093/cjip/povo08]. 
a less Western ruled society with the emergence of new poles of power. The economic rise of emerging economies and their influence as poles of dynamism is gradually translating to the political sphere. Thirdly, the concept of power has evolved towards definitions that are less materialist, opening a research ground for new notions as influential as soft power. Moreover, more classic theoretical concepts such as diplomacy, institutions or identity have vividly resurged and its influence spreads both within the system and also among political leaders. Finally, economic interdependence and globalization have erased Cold War's considerations about the poles of influence and even the most antagonistic states maintain strong economic relations.

\section{(I) The materialist analysis of hegemony}

Despite the transformations that are shaking international society, power distribution constitutes one of the most important variables in IR. The literature around power dynamics and distribution generally agrees in the difficulties to make power measurables7. Needless to say, historically power has been one of the most contested concepts in the literature, and the ways to measure it are, at least, plural. Moreover, any aggregated analysis of power must tackle the question of power fungibility, as different power resources are not interchangeable ${ }^{5}$. However, the alternative analyses also pose problems. On the one hand, the relational power approach, developed by Dahl, despite being useful, has been usually accused of mixing the concepts of power and controls9 and poses some difficulties to be studied. On the other hand, the concept of structural power, defined as the ability to establish the rules and influence other actors, is especially focused on the economy and regime theory that has not completely spilled over to the IR literature. Moreover, this last concept is profoundly influenced by the distribution of capabilities within the system, so both approaches are, in some way, interrelated ${ }^{60}$.

The role of the distribution of power and the structure of the international system has been a particular concern of realism. As Barnett and Duvall rightly affirmed, rival theories have just confronted argumentatively realists' concepts of power, but have not tried to construct their own definition of the concept and, at the same time, have strongly neglected to explicitly explain how it operates in their own theories $^{6 .}$. With its interest rooted as back as in Ancient Greece's philosophy, Thucydides believed, in Gilpin's words, that "the hierarchy of power among these states defined and maintained the system and

57 Underneath any power analysis, it coexists a debate between the consideration of power as resources or power as relational. As Baldwin notes, "the multidimensional nature of power makes it difficult to add up the various dimensions in order to arrive at some overall estimate of an actor's power". D. Baldwin, "Power and International Relations" in W. Carlsnaes, T. Risse-Kappen and B. A. Simmons (eds.), Handbook of International Relations (Sage, London, 2002) 273-297, at 275. Among realists, the notion of power as resources has been the more common one. However, this approach usually equates resources with power itself, neglecting the problems of conversion and the differences between capabilities and resources. Reus Smit, supra 47, at I6I-I62.

58 D. Baldwin, "Power Analysis and World Politics: New Trends versus Old Tendencies", 3I(2) World Politics, (I979) I6II94, at I80, [doi: $10.2307 / 200994$ I].

59 R. Dahl, "The Concept of Power", 2(3) Behavioral Science, (1957) 201-215, at 202-203, [doi: 10.1002/bs.3830020303].

60 J. A. Hart, "Power and Polarity in the International System" in A. N. Sabrosky (ed.), Polarity and War. The Changing Structure of International Conflict, (Westview Press, Colorado, 1985) 25-40, at 25 and 30.

$6 \mathrm{r}$ M. Barnett and R. Duvall, "Power in International Politics", 59(I) International Organization, (2005) 39-75, at 4I, [doi: I0.1017/S0020818305050010]. 
determined the relative prestige of states, their spheres of influence, and their political relations" ${ }^{62}$. Even though power has been understood in different ways among realists, it is undeniable that it constitutes the cornerstone for all the realist school. In neorealism, power was given even a stronger relevance. In Waltz words, international politics is a reflection of the distribution of power $\mathrm{r}^{63}$. In the same vein, Gilpin specified that the important factor was not the static power distribution, but the evolution of the dynamics of power relations ${ }^{64}$. Thus, power is not such important in absolute terms, but in relative ones.

At this point, it is possible to tag the distribution of power among great powers as a crucial variable for the materialist analysis. Great powers are usually defined by the combination of capabilities in several scopes ranging from economic strength, military budget or technology $y^{65}$. In contrast, Levy offers a less materialist vision, maintaining that great powers can be identified by three main characteristics. The first is their huge military capability and their projection of power abroad. As a result, great powers tend to be strategically self-sufficient and have strong foreign policy targets. Secondly, their concept of security is not only regional but global. Finally, they have both the capacity and the assertiveness to defend their interests globally ${ }^{66}$. This composed conceptualization of great powers supports the present multidimensional analysis that will start, but not finish, with the material structure.

By turning to a more analytical definition, Levy avoids the criticism towards materialist views, led by Waltz, which tend to wrongly equate capabilities and resources. In Reus-Smit's view, some of the components of Waltz' lists are resources, and just two can be equated as capabilities (economic and military strength) ${ }^{67}$. Therefore, most of IR literature assumes the equation that sees capabilities and resources as synonyms and analyses power just in terms of the addition of all of them.

Despite of analyzing each variable individually, it is also interesting to apply an index that offers a broader picture of the structure of international society. In the power transition literature, the Correlates of War (COW) project launched its own index to determine the outbreak of war caused mainly by power transition ${ }^{68}$. As a result of this project and applying different variables (population, military personnel, military expenditures, energy consumption and iron and steel production), it came

\footnotetext{
62 Gilpin, supra n. 21, at 595.

63 K. N. Waltz, "Structural Realism after the Cold War", 25(I) International Security, (2000) 5-4I, at 27, [doi: I0.1162/0I6228800560372].

64 Gilpin, supra n. 6, at 93.

65 Waltz, for example, lists the following variables: size of population and territory; resource endowment; economic capability; military strength; political stability; and competence. K. N. Waltz, Theory of International Politics, (McGraw-Hill, London, 1979) at I3I.

${ }_{66}$ J. Levy, War and the Modern Great Power System, I495-1975, (University Press of Kentucky, Lexington, I983) at II-I9.

67 Reus-Smit, supra 47, at I6I-I62.

68 The main works in the COW Project are Singer's introductory books that enunciate which variables and indicators will be included in the analysis. J. D. Singer, The Correlates of War, (Collier Macmillan, New York, 1979); J. D. Singer and P. Diehl, Measuring the Correlates of War, (University of Michigan Press, Michigan, 199I). For applications of the Correlates of War to power transitions see, for example, I. de Soysa, J. R. Oneal and Y.-H. Park, "Testing Power-Transition Theory Using Alternative Measures of National Capabilities", 4I(4) The Journal of Conflict Resolution, (1997) 509-528 [doi: 10.II77/0022002797041004002]; H. Houweling and J. G. Siccama, "Power Transitions as a Cause of War", 32(I) The Journal of Conflict Resolution, (1988) 87-I02, [doi: I0.II77/002200278803200I004]; D. Lemke and S. Werner, "Power Parity, Commitment to Change, and War", 4O(I) International Studies Quarterly, (1996) 235-260, [doi: I0.2307/2600958].
} 
up a Composite Index of National Capability (CINC) that ranked the states on the basis of its aggregate share of capabilities ${ }^{69}$. As Chan points out, the index was not very sensitive to economic changes, due to the importance given to variables such as population and the omission to adapt to the technological changes. As a result of that, the author maintains, this index did not reflect the decline of USSR power during the I970s and I980s and has lost most of its validity for the study of power transitions both in the 2Ist century and in the second half of the 2oth ${ }^{\circ}$. Therefore, Chan proposes an alternative measure that comprises economic power (through the indicator of GDP in US dollars on Purchasing Power Parity standard), defensive power (military expenditures in current US dollars) and technological power (total number of internet hosts $)^{71}$.

In the case of geographical variables such as population and territory, this methodology proposes to exclude them. As relative stable variables, they tend to bias the data by exaggerating the index of large and highly populated states such as Russia, China, India or the United States. It is not to say that they do not play a role as a factor of national power, but definitely is not a crucial one ${ }^{22}$.

In the same vein, with the purpose of offering an index that matches contemporary changes in international society, important attention should be paid to technological developments, both in the field of general innovation and to technologies on the military sector. In the latter, it is possible to state that, even if years ago the number of national troops was one of the most important indicators of each state's national military strength, recent developments in the military research and development sector provide the opportunity to develop a more lethal military with less personnel.

That being said, the aggregate power of a state is highly influenced by its economy. In the globalized world, national economy continues to be the most important material factor, even if its influence has diffused. Countries' economic strength determines most of the budget spent on military or social targets and also modifies their international strategy. Following economic variables, military, energy and technological ones will be individually addressed.

\section{(a) Economic, financial and technological variables}

Economic trends and the dynamism of national growth are usually marked as the most important variables of material power. Economic strength has been labelled as the most convertible form of power ${ }^{73}$. As Kirshner says, changes in the global economic map are one important source of international political

69 CINC includes the ratios of countries' (I) total population, (2) urban population, (3) iron and steel production, (4) primary energy consumption, (5) military expenditure, and (6) military personnel. It is, in fact, a multiple index that reunited demographic, industrial and military variables.

$7_{0}$ S. Chan, China, the U.S., and the Power-Transition Theory. A Critique, (Routledge, London, 2008) at 12.

$71 \quad$ Ibid, at $\mathrm{I3}$.

72 Chan is also a supporter of this claim. In his analysis, he has found that the addition of these variables has sometimes biased past analyses, as in the case of the United Kingdom. Ibid, at 2. Even if several leading scholars continue to include them in their analysis, the author understands that in the contemporary era both variables maintain relatively stable figures, unless a sudden loss of territory or population happens as a result of a war, for instance.

73 D. M. Lampton, The three faces of Chinese power: might, money, and minds, (University of California Press, California, 2008) at II4. 
conflict, as economic change is believed to redistribute relative power among states ${ }^{74}$.

Needless to say, the size of a state's economy is the cornerstone of great power status, and the economic surplus dedicated to military and technology is a reinforcing factor for rising powers ${ }^{75}$. Due to the more important role of emerging markets in the global economy, it is also important to look at the dynamism of the economy and its annual growth rate. As several authors argue, an economy's ability to grow is directly related to its maturity. Even if the technological revolution and reliable political environments maintain stable growth rates among developed societies, they are strongly confronted by developing economies whose growth-rates are far more dynamic ${ }^{76}$.

The measure of national economies and its international comparison has been commonly addressed through the use of Gross Domestic Product (GDP) indicators. However, there are several measurements for this task and lately there has been a wide controversy due to the different results that each one offered. Since the World Bank (WB) revised its indicators in the last decade, the measurement of GPP in Purchasing Power Parity (PPP) terms has witnessed a strong rise. As the Asian Development Bank (ADB) explains, this measure, "adjusts for differences in purchasing power of local currencies" 7 . With an admitting margin of error of $5 \%$, the WB advises to use this index to group economies, for example, in terms of their income, rather than ranking international economies ${ }^{7}$. Moreover, several economic analyses point out that the PPP is particularly troublesome in the case of larger countries with diverse prices between regions ${ }^{9}$. As in the case of China, the difference between urban areas (where most of the data is collected) and poorer rural areas creates an overestimation of actual prices ${ }^{80}$. As a result, economists tend to believe that PPP based index is not a proper tool for comparison, especially in cases like China ${ }^{8_{1}}$. Therefore, the GDP measure will be calculated in terms of nominal considerations. This way, the GDP at market prices in current dollars will not reflect the effects of inflation ${ }^{8_{2}}$.

To address the material bases of hegemony, the economic review should inevitably explore the

74 J. Kirshner, "The Tragedy of Offensive Realism: Classical Realism and the Rise of China", r8(I) European Journal of International Relations, (2012) 53-75, at 54, [doi: 10.II77/1354066110373949].

75 Gilpin, supra n. 2I, at 596.

76 R. L. Tammen, J. Kugler, D. Lemke, et. al., Power Transitions. Strategies for the 2Ist Century, (Chatham House, Nueva York, 2000) at $\mathrm{I} 6$.

77 Asian Development Bank, "Purchasing Power Parities and Real Expenditures", Asian Development Bank, Manila, 2007, $<$ http://siteresources.worldbank.org/ICPINT/Resources/270056-I255977254560/Asia\&Pacific_2005Report.pdf> [25th April 2016], at 8 .

${ }_{78}$ World Bank, "Global Purchasing Power Parities and Real Expenditures - 2005 International Comparison Program", World Bank, Washington DC, 2008, <http://siteresources.worldbank.org/ICPINT/Resources/icp-final.pdf> [25th April 2016], at 6.

79 A. Deaton and A. Heston, "Understanding PPPs and PPP-based national accounts", 2(4) American Economic Journal: Macroeconomics, (20I0) at I-35, [doi: I0.1257/mac.2.4.I].

80 R. C. Feenstra et al., "Who Shrunk China? Puzzles in the Measurement of Real GDP", 123 (573) The Economic Journal, (2013) IIOO-II29, at IIOI, [doi: IO.III/ecoj.I2O2I]. In the case of China, the prices were collected in in municipalities and extrapolated by the World Bank and the Asian Development Bank. World Bank, supra $\mathrm{n} 77$, at 7 .

${ }_{81}$ Even admitting that the data provided by the World Bank is "reasonable", Wolf and Pillingm strongly proclaim that they "don't mean that China is the largest economy". M. Wolf and D. Pillingm, "China: on top of the World", Financial Times, $2^{\text {nd }}$ May 20I4. See Y. H. Ferguson, "Rising powers and global governance. Theoretical perspectives" in J. Gaskarth (ed.), Rising powers, global governance, and global etbics, (Routledge, London, 2015) 2I-40.

${ }_{82}$ This measure can be found, for example, in Chan, supra n. 70. 
dynamics of trade. Needless to say, exportations have been an important variable for the rise of new powers and, in the way of becoming a mature economy, the balance of payments usually tends to equalize. Moreover, the relations between imports and exports provide a tool to identify imbalances in a national economy, as continuous trade deficits need strong injections of external capital in the domestic economy.

In this case, there is a strong advice to select the balance of payments in current market prices as an indicator. It is also important to examine the growth rates of both imports and exports to identify a tendency in each economy.

As it has been enunciated, the present methodological proposal prioritizes technological variables among geographical and demographical ones. It is not only that technological systems constitute a part of the international system, but also, as Herrera argued, produce a social, economic and political change ${ }^{83}$. Therefore, the transformative power of technology can be said to be a source of international change and, moreover, an important facet of national power. However, how to operationalize technological variables is sometimes a slippery issue ${ }^{84}$.

Hence, in the practical application, technological developments could be addressed via two main indicators. Firstly, the government expenditure on research and development $(\mathrm{R} \& \mathrm{D})$ measured by the percentage of national GDP. It is true that this indicator constitutes only one part of the R\&D investment, as private companies are, nowadays more than ever, important investors in this area. Secondly, there is important to trace exportations in high technology goods, as it reveals how competitive and innovative the national technology industry is.

\section{(b) Energy variables}

Besides the strong association between energy, geopolitics, foreign policy and diplomacy, this concept has also important implications in power status. As realists have remarked, resource shortage and reserves' insecurity may lead to a security dilemma ${ }^{85}$. Thus, states pursue, on the one hand, an improvement in the efficiency of their energy consumptions and, on the other, assuring their energy security. Therefore, energy variables can provide interesting information about systemic change in two different ways. First of all, energy consumption and the composition of each country's energy mix is a strong sign of the country's future energy needs. Even if this indicator can provide interesting information, it says merely nothing about power, but has the ability of suggesting the foreign policy projections of the hegemon and the rising power.

Secondly, energy indicators, particularly those linked to GDP, are useful to reveal a country's energy productivity and efficiency. In this vein, data linking GPD production and energy consumption digs into the technological and innovative character of a country, especially of its industry. Even if excluded

\footnotetext{
83 G. L. Herrera, Technology and International Transformation, The Railroad, the Atom Bomb, and the Politics of Technological Change, (State University of New York, New York, 2006) at 3.

${ }^{8}$ Because of the novelty of several technological innovations, it is really difficult to select technological variables and indicators that offer a determinant and reliable data for an extensive period of time.

85 J. A. Garrison, China and the energy equation in Asia. The determinants of policy choice, (FirstForumPress, Colorado, 2009) at 2.
} 
from the data, energy consumption and energy imports are also significant variables to analyse a country's national portfolio. However, towards an international comparison, productivity is by far a more determinant variable.

\section{(c) Military variables}

As Robert Art rightly pointed out, military force is integral to foreign policy ${ }^{86}$. Employed forcefully through its physical use or peacefully through intimidation, military power is a vital component of the great powers' portfolio of capabilities. Usually, military power is only described in its destructive sense ${ }^{87}$, but in addition, it includes others such as the ability to back up threats in coercive diplomacy, the capacity to protect and the provision of international assistance ${ }^{88}$. Therefore, the role of military power in the great power status is not only related to its capacity to win a war, but also to protect allies or to provide assistance in accidents or disasters.

Consequently, military expenditure and the size of an army continue to be a crucial facet of great power status. However, it must be noted that recent technological developments have expanded the effectiveness to kill with less personnel. The superiority of the US army, not just in terms of numbers, but also of technology, supports the counter-hegemonic claims towards military modernization. For this reason, military budgets of states should be understood not only as efforts to consolidate a stronger army, but also as an attempt to modernize their capabilities to match those of the hegemon.

An analysis of military power needs to start from state's annual military expenditures. However, this data is not totally reliable. Military issues continue to be sensitive topics and budget are usually released in accordance with governments' interests. Therefore, data had to be taken carefully, as budgets do not always include all the categories of military expenditure ${ }^{89}$. In this case, military power should be analysed, firstly, by the national expenditures in current US dollars and, secondly, by the weight of the military budget in national GDP.

(2) The social analysis of hegemony

The article has theoretically highlighted the complex and hybrid nature of the concept of hegemony. Even if material variables have been presented as relevant to the study of state's role, it is also necessary to understand them in a broader social picture. It is not only necessary to contextualize material variables within the dynamics and practices of international society. Moreover, how states decide to organize, understand and project them has a vital explanatory power. On this vein, in methodological

86 R. J. Art, "The Fungibility of Force" in R. J. Art and K. N. Waltz, The Use of Force. Military Power and International Politics, (Maryland, Rowman \& Littlefield, 2006) 3-19, at 3.

${ }_{87}$ Mearsheimer, for example, strongly supports that "great powers are determined largely on the basis of their relative military capability. To qualify as a great power, a state must have sufficient military assets to put up a serious fight in an allout conventional war against the most powerful state in the world". Mearsheimer, supra n 2I, at 5 .

88 J. S. Nye, Soft power: the means to success in world politics (Public Affairs, New York, 2004) at 42.

89 In the case of China, for example, the military expenditure proclaimed by the Chinese Government excludes some categories as, for instance, the procurement of foreign weapon systems. Department of Defense, "Annual Report to Congress. Military and Security Developments Involving the People's Republic of China 2014", Government of United States of America, Washington D.C., 20I4, at 43 . 
terms, there are three poles of social variables to advance towards a complete examination of hegemony in international society. The first one addresses the institutional practice of hegemony, through an analysis of the regimes and organization promoted by the hegemon from 1945 and its actual accommodation, as well as the nascent web of non-hegemonic institutions that are gradually concentrating alternative practices. Secondly, identity and socialization practices need to be addressed, paying special attention to the multiple identities that the hegemon and the rising state hold, as well as the processes of socialization, accommodation, and confrontation. Finally, the third pole suggest advancing towards an analysis of the legitimacy practices that take place within international society, which are highly influenced by material, institutional and identity variables.

\section{(a) Institutional order}

Even if institutions usually constitute a controversial object of study in international politics, the contemporary international society's growing institutional network raises its importance as relevant variables on the international. One can agree that institutions are a reflection of the distribution of material capabilities and that serve as tools of promotion of the interest of the dominant states, as neorealist have more than once stated. However, that seems a too simplistic argument to omit them in the analysis. Liberals' emphasis on institutions as the way to strengthen cooperation fails in the same mistake as the realist one ${ }^{9 \circ}$. As Reus-Smit argues, neither of these perspectives can explain why some institutions endure changes in the balance of power and why institutions that may seem conflictual emerge in the same structural conditions ${ }^{91}$.

As Keohane and Nye rightly expressed, hegemonic states usually opt to transform international norms and institutions instead of adjusting their own policies to the existing international environment ${ }^{22}$. Norms and institutions emerge as sources of consensual order derived from different interrelated dynamics. It can be argued that some norms and institutions emanate directly from critical changes that highlight the necessity of an institutional action, as environmental policies, for example. However, the hard corpus of contemporary institutional map derives from a given distribution of power within the system, in this case, a hierarchical one. Undeniably, the hegemon's normative and institutional preferences are not only a result of national policy calculations, but also influenced by subnational groups, elites and, to a lesser extent, imitation.

The case study will take advantage of different methodological tools to offer a broad map of the contemporary institutional practice and outline future institutional scenarios. Firstly, it is necessary to tackle the contemporary liberal international order, its main institutions, and the most recurrent patterns of institutional order and the global character of this order. Moreover, it is also interesting to

$90 \mathrm{Up}$ to some point, liberal institutionalist theory accepts the realist premise that point to the lack of information as the cause of the nonsuccess of cooperation. Even though realist treat information as a non-changing variable, liberal institutionalist argue that a more strengthened institutionalization contributes to a better and more regular information that may reduce uncertainty.

9r C. Reus-Smit, "The Constitutional Structure of International Society and the Nature of Fundamental Institutions", 5I(4) International Organization, (1997) 555-589, at 556, [doi: 10.1162/002081897550456].

92 R. O. Keohane and J. S. Nye, Power and Interdependence. World Politics in Transition, (Little Brown, Boston, I977) at 44. 
focus on the hegemon's participation in this order and its preference towards, for example, bilateral or multilateral cooperation depending on the area. As Mastanduno argues, U.S. institutional practices are driven by pragmatism, switching to bi- or multilateral patterns depending on the nature of its foreign policy targets and the opportunities and constraints of the international context $\mathrm{x}^{93}$.

Secondly, the participation of the rising state in this international order must be addressed. As Buzan affirms, in the case of the actual rising state, China, it is important to think about how best to characterize the relationship between this state and the international society ${ }^{94}$. In other words, it has to be contrasted Qin's opinion that maintains that China is increasingly pro status quo, not just instrumentally, but ideationally, as it accepts the values underlying the international society $y^{\text {s. Following }}$ Buzan, the dualism between status quo and reformism/revisionism comprises two questions at the same time: on the one hand, if the rising state is satisfied with its status in the international society and, on the other, whether it accepts or contests the institutions of the society.

The task of disentangling Chinese participation in the liberal institutional order should be addressed both quantitatively and qualitatively, through its participation in the institutions, its vote-share, its contribution to the budget (if there is any), and its decision-making. Moreover, it should be analysed the discursive use of institutions, in positive, neutral or negative sense, as well as its importance in the nations' foreign policy goals. However, prior to analysing states' behavior and strategies in the context of the selected institution, it should be examined each institution's resistance to change and its own paths to reform, if possible.

As a third main point, Chinese institutional building strategies should be studied, as an alternative to the hegemonic international order. For that purpose, the main driving principles to this strategy and the serving interest should be outlined. In other words, the alternative institutional frameworks constitute a basic clue to disentangle how China sees the world and which strategies will it follow in the future. In recent years, China has outlined which can be considered as the first steps towards this alternative institutional framework, with the launch of initiatives as the Asian Investment and Infrastructure Bank (AIIB), but also with the strengthening of bilateral cooperation and regional cooperation especially in Asia, Latin America, and Africa. Therefore, both the creation of these institutions, their goals and U.S. responses to these strategies should be carefully studied.

\section{(b) Identity and socialization}

In IR analysis, the role of identity gains special relevance in certain contexts defined by its complexity. Far from the ontological security that characterized the Cold War, the actual context is increasingly uncertain due to the rapid transformations of the international system. Identities, along with institutions and legitimacy, transform and give meaning to the distributions of power. Therefore,

93 M. Mastanduno, "Institutions of Convenience: U.S. Foreign Policy and the Pragmatic Use of International Institutions" in G. J. Ikenberry and T. Inoguchi (eds.), The Uses of Institutions: the U.S., Japan, and Governance in East Asia, (Palgrave Macmillan, New York, 2007) 29-50, at 31.

94 B. Buzan, "China in International Society: Is 'Peaceful Rise' Possible?”, 3(I) The Chinese Journal of International Politics, (2010) 5-36, at 16, [doi: 10.1093/cjip/popor4].

95 Qin Y., "Nation Identity, Strategic Culture and Security Interests: Three Hypotheses on the Interaction between China and International Society", (2) SIIS Journal, (2003). 
identities constitute important elements in the two-way relationship between agents and structure.

In the specific case of US hegemony and China's rise, identities play different roles. In a general sense, identities serve three main social functions: they tell the subject how is it, they tell the rest who the subject is and, finally, they tell the subject who are the rest ${ }^{96}$. However, the role of identities, in this case, becomes more complex. The relations between different subjects is usually understood as a Hegelian alter and ego relationship, where the alter transforms the ego's identity. In other words, this type of relation mirrors the victory of one of the subjects over the other. In great power relationships and power transitions, the Hegelian pattern is represented by portraying the rising challenger as a threat, both the identities of the hegemon and the rising power being exclusive. The struggle for great power status, therefore, is an exclusive relationship with only one victor.

As a result, the Western IR widespread view misunderstands emerging countries' processes of socialization that could break the forecasted spirals of power struggles in the international society. As an alternative, Qin Yaqing proposes the zhongyong (中庸) or Chinese dialectics, an inclusive relationship in which both subjects interact and complement themselves, giving rise to a new synthesis. The process plays an essential role, helping to the definition and redefinition of identities in the course of these relationships. Hence, as Wendt affirms, identities are always relational. The link between, on the one hand, actors' preferences and actions and, on the other, their identities and the ones they attribute to others, is an indivisible tie in the case of our discipline ${ }^{97}$. Moreover, identity definitions, as tools to distinguish alter and ego, involve specific definitions of which interest and threats affect national security ${ }^{98}$.

Even if identities are important for every state, they matter in different ways. In the case of the United States, as the hegemon of the system, its role implies the clash between two identities, as Cronin rightly illustrated 99 . The first one is its identity as a hegemon, related to notions of legitimacy and leadership; the second is its great power identity, connected to its material capabilities and its believed exceptional nature. Both maintain a tension between the audiences they relate to, international and domestic, and the clashing interests they demand. Therefore, it is important to address the identities the United States plays in international society and which type of actions corresponds to each of them. Moreover, following Yan Xuetong's works on the types of leadership, there must be addressed what type of leader the United States is, ranging from a tyrannical leadership based on military power, a hegemony founded in material power and strategic alliances and, finally, a model of human authority with a high degree of moral power ${ }^{100}$.

In the case of China, its label as a rising power leads, at least for realist theories, to tag it as a

96 H. Tajfel, Human Groups and Social Categories: Studies in Social Psychology, (Cambridge University Press, Cambridge, I98I) at 255 .

97 T. Hopf, "The Promise of Constructivism in International Relations Theory", 23(I) International Security, (1998) I7I200, at 175 y I78, [doi: 10.1162/isec.23.I.I71].

98 Katzenstein, supra n 39, at I8-I9; K. Booth, "Security and Self: Reflections of a Fallen Realist" in K. Krause and M. C. Williams (eds.), Critical Security Studies: Concepts and Cases, (University of Minnesota Press, Minneapolis, I997) 83-I20, at 88.

99 B. Cronin, "The Paradox of Hegemony: America's Ambiguous Relationship with the United Nations", 7(I) European Journal of International Relations, (200I) I03-I30, at I04-I05, [doi: 10.II77/I354066101007001004].

100 Yan X., "International Leadership and Norm Evolution", 4(3) The Chinese Journal of International Politics, (2011) 233- 
revisionist and as a threat to the system's stability. In these theories, a rising power has been purely defined by its increasing material capabilities. However, as Miller suggests, "rising powers are distinguished by very specific kinds of domestic beliefs" "ror. Rising powers, as candidates for great power status, will have an increasing influence in the international structure, the mayor processes and even the future developments of the international system. The development of a more inclusive category of rising power, with the addition of beliefs, identities, and interests, makes it possible to analyse Chinese future aspirations as a great power and its engagement with international responsibilities ${ }^{102}$. To advance an analysis of China's identity as a rising state, it is interesting to analyse the three types of behavior that usually these states accomplish ${ }^{\mathrm{ro}}$. Firstly, emerging powers seek to acquire more material capabilities to match those of the status quo states. The material approach will explore China's national power dynamics and their relative weight related to other states. Secondly, rising powers' national interests expand from a regional scope to a global one and become more complex. Therefore, its implication in the institutions and diplomatic arenas increases and its grand strategy evolves in that particular direction. Thirdly, rising states witness an increasing internal recognition of its growing status and wish to extend into external audiences. For this purpose, they usually develop communicative acts towards a reaffirmation of their role and their growing interests.

An analysis of identity provides the foundations of the alternative hegemonic institutions that both states propose. It will help in the identification of clashes and convergences and will provide the perfect starting point to determine the prospects to establish a legitimate hegemony.

\section{(c) Hegemonic legitimacy}

Legitimacy plays a crucial role in international society as the base of shared knowledge and the normative structure of the system ${ }^{\mathrm{ro4}}$. As it has been stated previously, it constitutes an essential factor in the international system and constitutes a vital concept to understand hegemony. Moreover, as a practical concept, legitimacy is inherently linked to the other three constitutes of hegemonic power: material resources, institutional order, and identity. Firstly, although usually misunderstood, the relationship between the material resources of power and legitimacy is quite relevant. Material resources, in relative terms, have been usually considered as the unique source of power.

However, researchers that understand power as relational rather than relative stress the contribution of legitimacy to compulsory power by inducing voluntary compliance within the international society. Under this statement, power is not material, but social, because legitimacy is perceptual and, moreover, these perceptions are rooted in other social variables such as norms, beliefs, and values ${ }^{\text {ros. }}$. Two reasons strength this point. Firstly, legitimacy is linked to the institutions and regimes as well as to the

\footnotetext{
264, [doi: 10.1093/cjip/poror3].

ror M. C. Miller, "The Role of Beliefs in Identifying Rising Power", 9(2) Chinese Journal of International Politics, (2016) 2II-238, at 2II, [doi: I0.I093/cjip/powoo6].

I02 Ibid, at 237.

I03 Ibid, at 217.

${ }^{104}$ Bukovansky, supra n. 4, at 2.

ros M. Bukovansky, I. Clark, R. Eckersley et al., Special Responsibilities. Global Problems and American Power, (Cambridge University Press, New York, 2012) at 69-70.
} 
normative structure, not only because the perception of an actor as legitimate is made within the boundaries of these norms, but because of the role of the institutional structure as a legitimizing field. In other words, institutional participation is often a tool to gain legitimacy, as well as a recurrent violation of international norms and counter-institutional practice can eventually lead to legitimacy crisis.

Secondly, identities and legitimacy constitute two permeable fields. As legitimacy, especially in its substantive variant, is profoundly influenced by the actor's values, the identities above these values influence the perception of an actor as legitimate. That is, the identity it plays in certain contexts will profoundly influence others' perceptions. For instance, when the United States decided to contravene international norms and intervene in Iraq, it played its role as a great power to its internal audiences, instead of its identity as a hegemon bestowed with special responsibilities. This way, the practices derived from these actions undermined its legitimacy and, for some authors, generated a crisis or soft balancing behaviours ${ }^{\mathrm{I0}}$. On the same vein, legitimacy processes transform and determine the units in the social system, constituting not only a two-way process but a mutually transformative one.

Therefore, the analysis of legitimacy will inevitably derive from some of the conclusions drawn from other variables. However, legitimacy should be understood in its deeper sense. It is possible to identify two narratives of the concept in its relation with hegemony, the superficial and the constitutive. The superficial narrative highlights the notion of legitimate domination achieved with the internalization by secondary states of norms and principles socialized by the hegemon. This process, as defined by Ikenberry and Kupchan, results on the internalization of these norms and principles that guide these states' conceptions of order ${ }^{\mathrm{I} 07}$. However, this notion only highlights the direct returns of legitimacy and defines the process as unidirectional, missing the transformative effects of legitimacy on the hegemon's identity and the institution of hegemony as a whole. On the contrary, the constitutive notion understands legitimacy practices as dynamic and continuously contested narratives that transform endlessly the hegemon and secondary states' identity, as well as the international society.

As a consequence of this complexity, any analysis accomplished from the constitutive perspective will inevitably face methodological difficulties. Despite the difficulties derived from the social character and normative references of legitimacy, any constitutive notion must capture the transformative dynamics of legitimacy both in actors and in structures. In the present legitimacy analysis, there will be two referents (the United States and China) and the same dispensers of the legitimacy (i.e. the majority of the states in the international society). For that research purpose, it is helpful to apply Rapkin and Braaten taxonomy on the dimensions of legitimacy to identify the variables and indicators of the analysis ${ }^{\mathrm{io8}}$.

The first dimension is substantive legitimacy, directly related to shared values and norms, as well as

I06 R. A. Pape, "Soft Balancing Against the United States", 30(I) International Security, (2005) 7-45, [doi: I0.II62/0I62288054894607]; Reus-Smit, supra n 46; Reus-Smit, C., "International Crisis of Legitimacy... op. cit."; Hurd, supra n I5.

107 G. J. Ikenberry and y C. A. Kupchan, "The Legitimation of Hegemonic Power" in D. Rapkin (ed.), World Leadership and Hegemony, (Rienner, Boulder, 1990) 49-69, at 49.

ro8 Rapkin and Braaten, supra n. I3. 
shared knowledge. Concretely, it is composed of common goals, principles, and values that serve as justifications for any initiative or action ${ }^{\text {rog }}$. As substantive values are used as referential in hegemon's action, it must be addressed if clashes between the hegemon's and secondary states regarding particular policies are driven by differences in values or interest. To address the question of substantial legitimacy, two variables should be assessed. Firstly, it must be analysed if the differences between the referents and the dispensers of legitimacy are based on different values or different policies. In other words, it is necessary to resolve if these clashes between referents and international society are a result of differences in values (as, for example, constant references to human rights) or policy behaviour. Secondly, there must be tackled the main values of the idea driven international society for the different referents, as well as its resemblance with those of other states.

Understanding legitimacy not only as something substantive but also as procedural highlights the importance of the decision process. This process, in the contemporary institutional frame, is constitutional as it is open to participation and mitigates the asymmetries of power, in Ikenberry's view $^{\text {IO }}$. The procedural dynamic is divided into two levels, one related to the accessibility of the decisionmaking process and, the other related to strategic restraint in its broader sense. Regarding the first procedural constitutionalism, two variables may derive. Firstly, the existing tension between conflicting identities of the referents. As it has been addressed before, actors compile different identities with sometimes conflicting values ${ }^{\text {III }}$. The second variable is related to the implication of the dispensers of legitimacy in the policies and initiatives launched by the referents. Consequently, it must be analysed to what extent the states of the international society participate in concrete initiatives of the hegemon in the context of the War on Terror. Therefore, as an indicator, it should be investigated what is the main driver of foreign policy: the referents self-interests or the special responsibilities they are bestowed with by the international society ${ }^{\mathrm{II}}$.

Regarding the second procedural constitutionalism, related to strategic restraint, it advances in the study of the referents role's in the world, implying issues of self-restraint, reduced returns on power, moderation in policy, adherence to international law or institutional binding. There can be identified several indicators in this issue, such as the state's adherence to international law or, in other words, its involvement both in quantitative and qualitatively (the number of treaties signed or its role as leader or follower, for example), its institutional participation or its role as a great power bestowed by some

\footnotetext{
109 Ibid, at I22.

по Ibid; Ikenberry, supra n 8; G. J. Ikenberry, "Institutions, Strategic Restraint, and the Persistence of American Postwar Order”, 23(3) International Security, (1998-1999) 43-78, [doi: 10.2307/2539338].

III As Cronin illustrated, the hegemon plays different identities to different audiences. On the one hand, it is a hegemon for international audiences and should act as a responsible power. On the other hand, it plays the role of a great power, especially in its material sense, for the internal audiences that sometimes demand a more interest driven role. Cronin, supra $\mathrm{n}$ 98.

II2 The notion of special responsibilities, as developed by Bukovanski et al., is understood as a type of hierarchy profoundly related to the normative and ideational structures. They are defined as a "differentiated set of obligations, the allocation of which is collectively agreed and they provide a principle of social differentiation for managing collective problems in a world characterized by both formal equality and inequality of material capability". Bukovanski, Clark, Eckersley et al, supra n I04, at I3-16.
} 
special responsibilities.

Finally, the third legitimacy dynamic is related to the effectiveness of the state's exercise of power. Obviously, this will be more easily addressed in the case of the hegemon, but as the rising state's power practice is still in progress, there should be investigated through projects more than outcomes. This way, two variables are identified: the referents influence in the world, operationalized by an analysis of the formal and informal alliance map; and the different leadership models' compliance within global society through surveys and statistical data.

The application of this complex methodology will offer a multidimensional and multilevel understanding of the legitimacy of the confronting hegemonic institutions lead by the United States and China. Understanding legitimacy as a concept with continual references to material capabilities, identities, and institutions, the final analysis about conflicting hegemonic institutions will summarize the whole case study by offering a complete understanding of both models and the responses of the members of the international society.

\section{(F) CONCLUSION}

There is an evident need to build bridges between different research projects to construct a comprehensive approach that understands hegemony both as social and material concept. This lack of comprehensive approaches evidences the absence of fruitful dialogue between social and materialist research projects. As this article evidences, approaching the materialist analysis within the broader understanding of structure that is simultaneously material and social contextualizes better the data and empowers social analysis dialoguing directly with the main materialist understandings.

As Pu rightly expresses, "the gap between material power and ideational power constitutes a major disequilibrium in the international system, and this disequilibrium drives the major international political change" ${ }^{\text {II3 }}$. It is in this gap where this methodological proposal navigates, on identifying the disequilibrium between the material and the social that produce change on the overall structure.

Hence, the composed approach transforms conflicting approaches in complementary and spurs dialogue. This way, the transgression at this point is not the creation of new terms, but the elaboration of a "conceptual geography" of the discipline to advance analytically $y^{\text {II4. }}$

In a practical sense, the source of conflict under hegemonic leadership is the tension between the real distribution of material power and the hierarchical hegemonic international system. The different transformations that take place on the social and material structures translate in different ways; distribution of material power, for instance, changes more rapidly but social changes in the hegemonic international society are more profound even if they require longer periods of time.

The hierarchical hegemonic system was born under a certain distribution of power in which the state's primacy has no challenge. This system, once it becomes more and more operationalized through

${ }^{\mathrm{II}} \mathrm{Pu}$ X., "Socialisation as a Two-way Process: Emerging Powers and the Diffusion of International Norms", 5(4) The Chinese Journal of International Politics, (2012) 34I-367, at 353, [doi: 10.1093/cjip/posorz].

II4 A prominent example of this transgression is Barkin's work. J. S. Barkin, Realist Constructivism. Retbinking International Relations Theory, (Cambridge University Press, Cambridge, 20Io) at I55. 
instruments such as alliances, socialization and legitimacy practices, and institutions, orders a hierarchy of distribution of gains. As this distribution is locked by the social role of the hegemon, it automatizes and maintains nearly stable over time. However, simultaneously, the hegemon's material power base raises its maturity and the exercise of power raises the cost of hegemony, even if some of the burdens are spread among the system. More dynamic states rise in this distribution of power, especially in economic terms, while its status in the social hierarchy does not match its new material position. It does not only involve questions of status, identities or responsibilities, but also involvement in the decision-making processes and a better position in the hierarchy of the distribution of gains.

The neglect to accommodate its rising challenger constitutes, under this view, the worst scenario for the hegemon, as the rising state will push for overcoming that hierarchy once the gains of doing it overcome the costs. Evidently there is an inevitable clash of interest between both states, but this is worsened by the apparently independent functioning of both of them. Hence, the isolation of both structures spurs this absence of dialogue between them and stimulates the hegemon's blindness on the changes that the material distribution is pushing for. Theoretical analysis can, modestly, try to transform this and stimulate processes of accommodation that, at least, reduce the costs for the rising state. 